\title{
Rancangan Soal Open-Ended untuk Meningkatkan Kemampuan Penalaran Peserta Didik dalam Pembelajaran Sosiologi di SMA N 1 Sungai Aur Kabupaten Pasaman Barat
}

\author{
Panji Reski ${ }^{1}$, Ike Sylvia ${ }^{2}$ \\ ${ }^{1,2}$ Universitas Negeri Padang \\ Email: panjireski223@gmail.com, ikesylvia@fis.unp.ac.id
}

\begin{abstract}
Abstrak
Penelitian ini dilatarbelakangi banyaknya soal ujian semester sosiologi SMA N 1 Sungai Aur yang berada pada rentang $\mathrm{C} 1-\mathrm{C} 3$ sehingga belum dapat mendorong munculnya kemampuan penalaran peserta didik, maka perlu adanya soal open-ended yang dapat digunakan pada pembelajaran sosiologi di kelas XI IPS. Penelitian ini bertujuan menghasilkan rancangan soal open ended yang yang valid. Teori yang digunakan untuk menganalisis adalah teori konstruktivisme, dengan asumsi kemampuan peserta didik memberikan alasan dan solusi dalam menjawab soal open ended akan membantu peserta didik mengkonstruksi konsep dari fenomena sosial yang dipelajarinya. Penelitian ini berjenis research dan development dengan model pengembangan yang dikemukakan oleh Tessmert (Formative Evaluation). Teknik pengumpulan data berupa tes dan angket. Uji validitas yang dilakukan adalah validitas konten dan konstruk. Peneliti memberikan soal yang telah dirancang kepada 3 orang ahli kemudian diujicobakan secara one to one dan small group pada 11 orang peserta didik di kelas XI IPS 2. Selanjutnya soal tersebut juga diuji analisis butirnya sehingga menghasilkan rancangan soal open ended untuk materi struktur sosial, diferensiasi sosial dan stratifikasi sosial dengan bentuk soal adalah 20 pilihan ganda dan 5 soal essay yang valid. Hasil penelitian menunjukkan bahwa soal open-ended ini sangat valid dengan nilai $85,71 \%$. Sementara dari angket praktikalitas diperoleh 4,52 kategori sangat praktis. Artinya bahwa soal open-ended valid dan dapat digunakan untuk mengukur kemampuan penalaran peserta didik pada skala yang lebih luas.
\end{abstract}

Kata Kunci: Kemampuan Penalaran, Open-Ended, Soal

\section{Abstract}

This research was motivated by the large number of sociology semester exam questions at SMA N 1 Sungai Aur which were in the range $C 1-C 3$ so that it could not encourage the emergence of students' reasoning abilities, it was necessary to have open-ended questions that could be used in sociology learning in class XI IPS. This study aims to produce a valid open-ended question design. The theory used to analyze is constructivism theory, with the assumption that the ability of students to provide reasons and solutions in answering open-ended questions will help students construct concepts from the social phenomena they are learning. This research is a research and development type with a development model proposed by Tessmert (Formative Evaluation). Data collection techniques in the form of tests and questionnaires. The validity test is the content and construct validity. The researcher gave the questions that had been designed to 3 experts and then tested them one to one and small groups on 11 students in class XI IPS 2. Furthermore, the item analysis was also tested to produce an open-ended question design for material social structure, social differentiation. and social stratification with 20 multiple choice questions and 5 valid essay questions. The results showed that this open-ended question was very valid with a value of $85.71 \%$. While the practicality questionnaire obtained 4.52 very practical categories. This means that open-ended questions are valid and can be used to measure students' reasoning abilities on a broader scale.

Keywords: Open-ended, Problem, Reasoning Ability

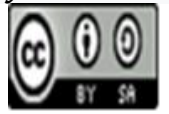

Received: January 17, 2021 $\quad$ Revised: February 8, 2021 Accepted: February 9, 2021 


\section{Pendahuluan}

Pendidikan mempunyai peranan penting bagi keberlangsungan suatu bangsa. Selain mewujudkan manusia yang berkualitas, pendidikan juga merupakan bagian yang integral dalam pembangunan, sehingga perlu untuk mengupayakan agar proses pembelajaran dapat membuat peserta didik mengembangkan kemampuannya. Manusia yang berkualitas dapat menjadi tenaga penggerak demi terciptanya kemajuan pembangunan. Oleh karena itu peningkatan kualitas pendidikan adalah salah satu urgensi yang harus dilakukan, hal yang paling fundamental adalah mengubah pola pikir dan sifat peserta didik dalam mengembangkan kemampuannya untuk dapat menjadi sumber daya manusia yang unggul.

Ada beberapa kecakapan yang harus dimiliki oleh setiap individu agar tetap bersaing dan diperhitungkan dalam kehidupan pada abad ke-21, yaitu, (1) critical thinking and problem solving, (2) collaboration, (3) good communication, (4) creative and innovative thinking skill, (5) social responsibility, (6) work ethic. Oleh karena itu pemerintah mengupayakan peningkatan kualitas pendidikan di Indonesia melalui implementasi Standar Nasional Pendidikan yang terdiri dari delapan komponen yaitu standar isi, standar proses, standar kompetensi lulusan, standar pendidik dan tenaga pendidikan, standar sarana dan prasarana, standar pengelolaan, standar pembiayaan, serta standar penilaian pendidikan, sehingga keselarasan antara proses pembelajaran dan penilaian harus dilakukan agar peserta didik mampu mengoptimalkan kompetensi pengetahuan, sikap dan keterampilan untuk mampu menghadapi tantangan di abad ke 21. (Sylvia, Anwar, \& Khairani, 2019).

Dalam Kurikulum 2013 tepatnya pada standar isi dalam Peraturan Menteri Pendidikan dan Kebudayaan Nomor 21 Tahun 2016 (Kemendikbud, 2016), mengenai kompetensi inti bagian keterampilan dijelaskan bahwa peserta didik dituntut untuk memiliki keterampilan menalar, mengolah, dan menyaji secara effective, creative, productive, critical, independent, collaborative, communicative, solution. Berkaitan dengan hal tersebut terlihat bahwa output dari sebuah pembelajaran yang diharapkan muncul pada peserta didik salah satunya adalah kemampuan menalar yang sangat penting untuk dikembangkan.

Menurut Lithner (Konita, M., Asikin, M., \& Noor Asih, 2019) kemampuan menalar merupakan suatu kegiatan, proses atau aktivitas berpikir untuk menarik kesimpulan atau membuat suatu pernyataan baru berdasarkan beberapa pertanyaan yang diketahui benar ataupun yang dianggap benar. Hal senada juga diutarakan oleh Moshman (Konita, M., Asikin, M., \& Noor Asih, 2019) yang mengatakan bahwa penalaran adalah suatu aktivitas berfikir yang bertujuan untuk mencapai kebenaran atau kesimpulan yang benar. Pendapat yang lain tentang pengertian penalaran juga diutarakan oleh Suherman (Konita, M., Asikin, M., \& Noor Asih, 2019) menjelaskan bahwa penalaran merupakan cara berpikir yang digunakan untuk menghasilkan suatu pernyataan dan kesimpulan. Sehingga dapat disimpulkan bahwa kemampuan penalaran merupakan suatu kemampuan berpikir yang bertujuan untuk menarik kesimpulan dari beberapa pertanyaan yang dianggap benar.

Keberhasilan guru dalam dalam mencapai tujuan pembelajaran dapat dilihat dari penilaian atau evaluasi. Penilaian merupakan suatu kegiatan yang bertujuan untuk mengukur dan memberikan penilaian kepada suatu objek berdasarkan patokan dan kriteria tertentu (Yusuf, 2015). Sementara itu Bloom dan Silverius dalam (Adi, 2010) menyatakan bahwa evaluasi adalah pengumpulan data secara sistematis dari peserta didik yang digunakan untuk melihat sejauh mana perubahan terjadi pada diri peserta didik. Dapat disimpulkan bahwa penilaian atau evaluasi adalah suatu kegiatan yang bertujuan untuk menentukan serta melihat perubahan yang ada pada peserta didik agar peserta didik mampu mencapai apa yang harus dicapai.

Untuk mengetahui kemampuan penalaran peserta didik dapat diukur dengan menggunakan tes yang diberikan dalam evaluasi pembelajaran. Tes adalah suatu prosedur yang spesifik dan sistematis untuk mengukur tingkah laku seseorang, atau suatu pengukuran yang

Jurnal Sikola: Jurnal Kajian Pendidikan dan Pembelajaran Vol. 2, No. 3, Th. 2021 
bersifat objektif mengenai tingkah laku seseorang, sehingga tingkah laku tersebut dapat digambarkan dengan bantuan angka, skala atau dengan sistem kategori (Yusuf, 2015). Tes adalah seperangkat penilaian, suatu penilaian diharapkan dapat bermanfaat serta mampu melakukan fungsinya agar dapat menunjukkan hasil estimasi yang tepat dan terukur (Dessy Febyronita, 2016). Biasanya soal ada dalam setiap tes dalam pembelajaran. Soal menurut A Muri Yusuf (Yusuf, 2015) adalah sesuatu yang menuntut jawaban dari pertanyaan. Melalui soal peserta didik mampu untuk meningkatkan kemampuan dan potensi mereka sehingga soal yang dibuat guru haruslah memiliki tipe yang dapat memberikan ruang bagi peserta didik untuk mengeluarkan kemampuan yang ada pada diri peserta didik. Tes yang digunakan untuk mengukur kemampuan penalaran peserta didik haruslah menggunakan soal yang memuat kemampuan penalaran.

Peserta didik di SMA N 1 Sungai Aur khususnya pada pembelajaran sosiologi belum terbiasa untuk mengerjakan soal-soal dalam kategori non-rutin. Soal non-rutin yaitu soal yang diperlukan pemikiran lebih lanjut karena prosedurnya tidak sejelas atau tidak sama dengan prosedur yang di pelajari di kelas (Z Lewy, 2009). Dapat juga dikatakan sebagai soal yang membutuhkan kemampuan penalaran untuk menemukan penyelesaiannya (Dahlan, Rohayati, \& Karso, 2012). Pengukuran kemampuan peserta didik dalam pembelajaran sosiologi masih didominasi oleh soal-soal sederhana, dalam artian soal-soal dengan cara penyelesaian yang sudah jelas, yaitu soal dengan cara penyelesaian tunggal bukan yang bersifat open-ended. Atau dapat dikatakan sebagai soal rutin, yaitu soal latihan biasa yang dapat diselesaikan dengan prosedur yang dipelajari di kelas (Z Lewy, 2009). Hal tersebut menyebabkan ketidakmampuan siswa dalam berpikir menalar dengan memanfaatkan materi-materi yang mereka pahami. Ini menjadi salah satu kelemahan dalam pengembangan kemampuan penalaran peserta didik. Kelemahan tersebut dibuktikan dari hasil analisis soal ujian akhir semester genap yang diujikan SMA N 1 Sungai Aur semester Januari-Juni tahun 2020 pada mata pelajaran sosiologi yang dapat dilihat pada tabel di bawah ini:

Tabel 1. Soal Pilihan Ganda dan Uraian (Essay) SMA N 1 Sungai Aur

\begin{tabular}{|c|c|c|c|c|c|c|c|}
\hline \multirow{2}{*}{ No Lingkup Materi } & \multicolumn{6}{|c|}{ Taksonomi } & \multirow{2}{*}{ Jumlah } \\
\hline & (C1) & (C2) & (C3) & (C4) & (C5) & (C6) & \\
\hline 1. Konsep & 5 & 15 & 3 & - & - & - & 23 \\
\hline 2. Fakta & 6 & 16 & 5 & - & - & - & 27 \\
\hline 3. Prinsip & - & - & - & - & - & - & - \\
\hline Total & 11 & 31 & 8 & - & - & - & 50 \\
\hline
\end{tabular}

Sumber: Arsip Bundel Soal Ujian Sosiologi MKKS Kabupaten Pasaman Barat Semester Genap 2019/2020 (Semester Januari-Juni 2020).

Data distribusi soal ujian akhir semester yang dirancang oleh MKKS Sosiologi Kabupaten Pasaman Barat di atas memperlihatkan bahwa soal yang diujikan dalam ujian semester masih dalam tingkat taksonomi C1, C2 yang masih tergolong LOTS (low order thingking skills) dengan jumlah 42 soal dan C3 yang tergolong MOTS (middle order thingking skills) dengan jumlah 8 soal. Sedangkan soal dalam tingkat C4, C5, C6 yang tergolong HOTS (higher order thingking skills) tidak ditemukan. Dari soal yang diberikan di SMA yang ada di Pasaman Barat tampak jelas bahwa proses pengukuran pembelajaran tidak menuntut peserta didik untuk memiliki kemampuan analisis (C4), evaluasi (C5), menciptakan (C6) terlihat dari $\mathrm{KKO}$ yang digunakan dalam soal yang diujikan. Hal ini tentu tidak sesuai dengan harapan yang tertuang pada kurikulum yang digunakan yaitu kurikulum 2013. Deskripsi data di atas menunjukkan pelaksanaan penilaian pembelajaran yang terjadi masih menggunakan soal yang berada pada tingkatan C1, C2 yang tergolong (LOTS) yang tidak memberikan ruang bagi peserta didik untuk

Jurnal Sikola: Jurnal Kajian Pendidikan dan Pembelajaran Vol. 2, No. 3, Th. 2021 
mengeluarkan kemampuan penalarannya, jenis soal seperti ini akan mengakibatkan peserta didik tidak dapat untuk mengeluarkan kemampuan penalarannya. Setelah dilakukan observasi dan wawancara dengan guru sosiologi SMA N 1 Sungai Aur diperoleh penjelasan bahwa selama ini soal yang sering diujikan kurang bervariatif dan masih pada tataran $\mathrm{C} 1, \mathrm{C} 2, \mathrm{C} 3$ yang tergolong taksonomi LOTS dan MOTS, karena output proses pembelajaran yang dilaksanakan diukur melalui soal rutin yang memiliki jawaban tunggal dan belum terbiasa mengasah kemampuan peserta didik mengemukakan kemampuan analisis berdasarkan hasil elaborasi dari berbagai sumber belajar yang dipahami terkait materi yang dibelajarkan, sehingga dapat dikatakan belum memberikan ruang dan kesempatan kepada peserta didik untuk mengeluarkan kemampuan penalarannya. Untuk itu dibutuhkan pengembangan perangkat tes berupa soal open-ended (terbuka) yang dapat meningkatkan kemampuan penalaran peserta didik. Soal ini didesain dengan memiliki banyak alternatif penyelesaian sehingga peserta didik bebas untuk memilih dan mengemukakan jawaban sesuai dengan pemahaman peserta didik. Ada dua macam produk soal yang akan dikembangkan peneliti yaitu: soal pilihan ganda dan soal uraian/essay disertai alasan menjawab. Menurut (Melianingsih, Nuning, \& Sugiman, 2015) bahwa soal-soal open ended merupakan soal-soal yang tidak lengkap atau terbuka yang memberikan beranekaragam hasil jawaban sehingga memberikan pengalaman bagi peserta didik untuk menemukan sesuatu yang baru dalam penyelesaian masalah. Pemberian masalah tersebut bukan untuk menemukan jawaban tetapi mencari strategi, cara dan pendekatan untuk sampai pada jawaban dari masalah yang diberikan.

Artikel ini bertujuan untuk mendeskripsikan hasil penelitian rancangan soal open-ended untuk meningkatkan kemampuan penalaran peserta didik dalam pembelajaran sosiologi di SMA N 1 Sungai Aur Kabupaten Pasaman Barat khususnya pada materi kelas XI yang terdapat pada KD. 3.3 yaitu Struktur Sosial, Diferensiasi Sosial dan Stratifikasi Sosial.

\section{Metode Penelitian}

Jenis Penelitian yang dilakukan menggunakan penelitian pengembangan (research and development) (Sugiyono, 2017). Dalam pengembangan soal ini, model yang dipakai ialah model yang dipaparkan oleh ahli, yakni Tessmer (formative evaluation) yang meliputi beberapa prosedur/ langkah-langkah, antara lain: tahap preliminary, tahap self evauation, tahap prototyping (validasi, evaluasi, dan revisi), dan tahap field test. (Mardiani \& Sylvia, 2019). Rancangan soal-soal openended ini dilakukan melalui dua tahapan yaitu priliminary study dan tahap formatif study. Tahap priliminary meliputi persiapan dan desain sedangkan tahap formatif meliputi Self Evaluation, Expert Reviews, One to One, Small Group dan Field Tes. Tahapan tersebut dapat digambarkan sebagai berikut:

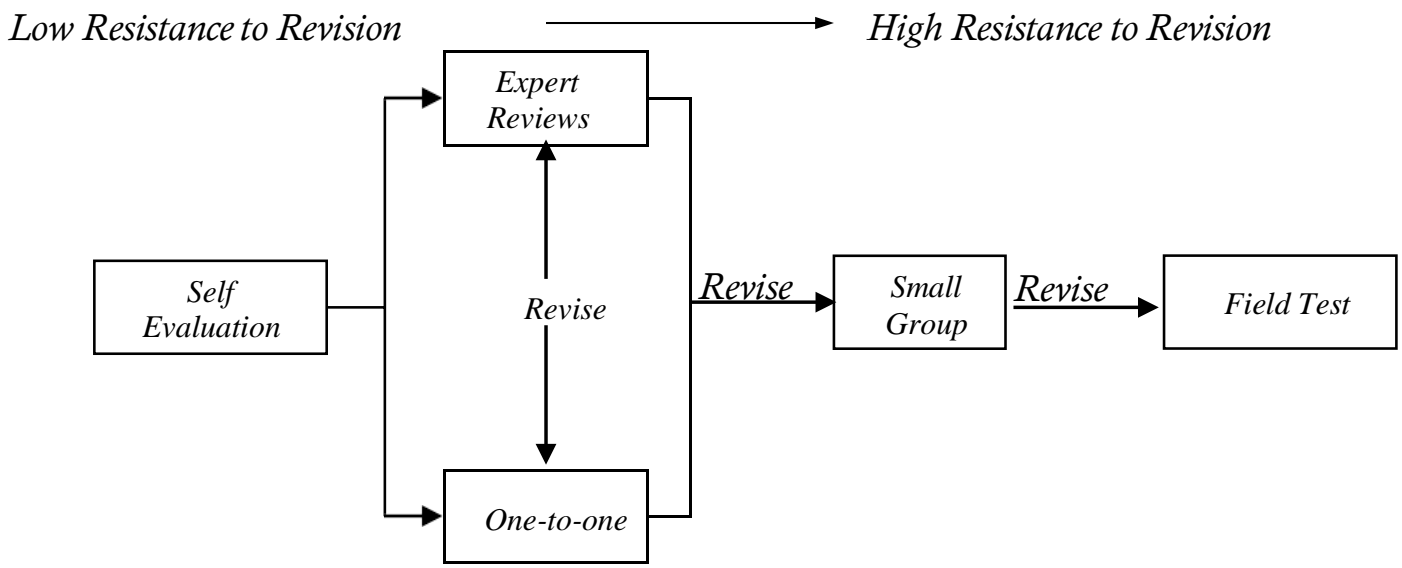

Gambar 1. Alur Desain Formative Research

Jurnal Sikola: Jurnal Kajian Pendidikan dan Pembelajaran Vol. 2, No. 3, Th. 2021 
Preliminary terbagi menjadi 2 tahap yaitu pertama tahap persiapan, pada tahap ini meliputi analisis materi dan perancangan instrumen penilaian soal open ended. Pada tahap ini peneliti melakukan analisis awal dengan mengumpulkan data dari bermacam sumber yang berkaitan dengan penelitian pengembangan soal open ended, kemampuan peserta didik serta materi stratifikasi sosial. Tahap ini bertujuan untuk menetapkan serta mendefenisikan kebutuhan dalam pembelajaran sosiologi dengan menganalisis tujuan serta materi. Tahap ini terdiri atas kajian pustaka serta kajian data dokumen hasil proses pembelajaran. Kajian pustaka dilakukan untuk mengumpulkan bermacam data yang diperlukan dalam proses pengembangan soal open ended yaitu dengan cara mempelajari bacaan tentang penilaian pendidikan yang membahas mengenai soal open-ended yang digunakan untuk meningkatkan kemampuan penalaran peserta didik. Sedangkan untuk mendapatkan data dan realitas pada proses penilaian di dalam kelas maka dilakukan kajian data dokumen hasil proses pembelajaran. Setelah melakukan observasi, wawancara serta meneliti dokumen terkait proses pembelajaran dan penilaian peneliti memperoleh sekolah ini sudah menerapkan kurikulum 2013. Dengan adanya kurikulum tersebut maka akan disesuaikan materi yang akan digunakan untuk penelitian produk ini. Dan peneliti dalam hal ini mengambil materi struktur sosial, diferensiasi sosial dan stratifikasi sosial dalam pengembangan soal ini. Pemilihan materi ini didasarkan pula pada banyaknya kemungkinan fenomena sosial yang dapat dipahami oleh peserta didik terkait topik tersebut yang ada di lingkungan sekitar mereka. Kemudian peneliti melakukan telaah dokumen nilai yang diperoleh peserta didik. Peneliti menemukan nilai peserta didik masih tergolong rendah karena proses pembelajaran sosiologi cenderung bersifat rutin. Guru jarang memberikan soal yang bisa memberikan ruang kepada peserta didik untuk berpikir menalar sehingga peserta didik tidak dapat meningkatkan kemampuannya untuk mencari sumber belajar lain dan terbiasa menjawab soal dengan jawaban tunggal. Dari beberapa alasan tersebut maka perlu dilakukan penelitian dan pengembangan soal open-ended sebagai evaluasi pembelajaran yang dapat digunakan sebagai bahan evaluasi di dalam kelas.

Selanjutnya tahap kedua yaitu penilaian formatif terbagi menjadi 6 tahapan yaitu: (1) Self Evaluation, dalam self evaluation, dilakukan penilaian oleh peneliti sendiri terhadap pendesainan soal-soal open-ended, (2) Expert Reviews, hasil desain pada self evaluation diberikan pada pakar (expert review). Tahap ini juga dinamakan sebagai uji validitas. (3) One to One, pada tahap one-toone, peneliti memanfaatkan seorang peserta didik kelas XI IPA 2 SMA N 1 Sungai Aur sebagai tester dan diminta mengamati dan mengkomentari soal-soal soal open ended. Hasil komentar peserta didik akan digunakan sebagai input untuk merevisi soal-soal open-ended (4) Small Group, pada tahap ini dilakukan uji coba pada small group (10 orang peserta didik yang bukan subjek penelitian untuk ujicoba luas) di kelas XI IPS 2 SMA N 1 Sungai Aur. (5) Revise dan (6) Field Tes. Namun pada penelitian ini peneliti tidak sampai pada tahap uji coba luas atau field test.

Metode pengumpulan data berupa: (1) Analisis dokumen yaitu analisis terhadap dokumen yang telah dirancang yaitu instrumen soal open ended yang telah dibuat sesuai dengan kisi-kisi soal yang dianalisis baik konten, konstruk dan bahasa oleh pakar, (2) Tes soal-soal open-ended, dengan tujuan untuk memperoleh data tentang keefektifan soal-soal open-ended maka dilihat efek terhadap kemampuan peserta didik menyelesaikan soal-soal open-ended (3) Walk Through, dilakukan dengan memberikan semua rancangan yang berisikan semua rancangan soal-soal openended kepada para pakar beserta instrumen validasinya, kemudian para pakar memberi komentar serta saran untuk setiap konten soal, konstruk dan bahasa yang terdapat dalam rancangan soal open ended untuk materi materi struktur sosial, diferensiasi sosial dan stratifikasi sosial dan (4) $\log$ Book, berisi semua komentar dan saran dari para pakar akan dicantumkan.

Adapun produk yang dikembangkan dalam penelitian ini adalah soal penalaran tipe HOTS open-ended berupa 20 soal objektif dan 5 soal uraian dengan bermacam alternatif jawaban disertai alasan menjawab. Untuk memperoleh rancangan soal open ended yang layak digunakan, 
peneliti menggunakan validitas isi dan konstruk. Dalam melakukan validasi isi butir soal, penulis meminta bantuan kepada 3 orang ahli/validator dari dosen pendidikan sosiologi dan guru sosiologi SMA $\mathrm{N} 1$ Sungai Aur. Ahli/validator menilai dan memberikan masukan menggunakan lembar validasi yang telah disediakan terhadap keempat paket instrumen yang telah disusun. Instrumen yang telah disusun beserta lembar validasi diserahkan kepada ahli/validator untuk dinilai dan diberikan masukan. Kemudian hasilnya dijadikan acuan untuk melakukan revisi agar instrumen siap diujicobakan. Jumlah soal dan soal mana saja yang akan diujicobakan dipilih berdasarkan masukan ahli/validator. Skor yang terdapat pada lembar validasi menggunakan skala 1 sampai 5 , dengan keterangan sebagai berikut: $1=$ sangat tidak sesuai: 2 = kurang sesuai; 3 = cukup sesuai; $4=$ sesuai; dan $5=$ sangat sesuai. Kemudian, dari skor tersebut dihitung indeks validitasnya untuk menentukan validitas isi instrumen. Rumus yang digunakan untuk memperoleh indeks validitas soal adalah rumus indeks Aiken $(V)$ yang dikemukakan oleh Retnawati, (2016:18), yaitu:

$$
V=\frac{\sum S}{N(C-1)}
$$

Keterangan:

$\mathrm{V}=$ indeks kesepakatan ahli mengenai validitas butir

$\mathrm{S}=\mathrm{R}-\mathrm{L}_{\mathrm{o}}$

$\mathrm{L}_{\mathrm{o}}=$ angka penilaian validitas terendah

$\mathrm{C}=$ angka penilaian validitas tertinggi

$\mathrm{N}=$ banyaknya ahli/validator

$\mathrm{R}=$ angka yang diberikan oleh ahli.

Kemudian soal yang telah divalidasi ahli dan direvisi menjadi rancangan soal open ended yang diasumsikan dapat meningkatkan kemampuan penalaran peserta didik yang kemudian siap untuk diujicobakan oleh guru pada pembelajaran sosiologi pada materi struktur sosial, diferensiasi sosial dan stratifikasi sosial.

\section{Hasil dan Pembahasan}

Berikut ini tahapan yang peneliti lakukan dalam menghasilkan rancangan soal open ended pada pembelajaran sosiologi SMA kelas XI materi struktur sosial, diferensiasi sosial dan stratifikasi sosial.

\section{Tahap Self Evaluation}

Pada tahap analisis ini, peneliti melakukan analisis awal dengan mengumpulkan data dari bermacam sumber yang berkaitan dengan penelitian pengembangan soal open ended, kemmampuan peserta didik serta materi stratifikasi sosial. Tahap ini bertujuan untuk menetapkan serta mendefenisikan kebutuhan dalam pendidikan dengan menganalisis tujuan serta materi. Tahap ini terdiri atas kajian pustaka serta kajian lapangan. Kajian pustaka dilakukan untuk mengumpulkan bermacam data yang diperlukan dalam proses pengembangan soal open ended yaitu dengan cara mempelajari bacaan tentang penilaian pendidikan yang membahas mengenai soal open-ended yang digunakan untuk meningkatkan kemampuan penalaran peserta didik. Sedangkan untuk mendapatkan data dan realitas pada proses penilaian di dalam kelas maka dilakukan kajian lapangan.

Setelah melakukan observasi, wawancara serta meneliti dokumen terkait proses pembelajaran dan penilaian peneliti memperoleh sekolah ini sudah menerapkan kurikulum 2013. Dengan adanya kurikulum tersebut maka akan disesuaikan materi yang akan digunakan untuk 
penelitian produk ini. Dan peneliti dalam hal ini mengambil materi struktur sosial, diferensiasi sosial dan stratifikasi sosial dalam pengembangan soal ini. Pemilihan materi ini didasarkan pula pada banyaknya kemungkinan fenomena sosial yang dapat dipahami oleh peserta didik terkait topik tersebut yang ada di lingkungan sekitar mereka.

Selanjutnya peneliti melakukan telaah dokumen nilai yang diperoleh peserta didik. Peneliti menemukan nilai peserta didik masih tergolong rendah karena proses pembelajaran sosiologi cenderung bersifat rutin. Guru jarang memberikan soal yang bisa memberikan ruang kepada peserta didik untuk berpikir menalar sehingga peserta didik tidak meningkatkan kemampuannya untuk mencari sumber belajar lain dan terbiasa menjawab soal dengan jawaban tunggal. Dari beberapa alasan tersebut maka perlu dilakukan penelitian dan pengembangan soal open-ended sebagai evaluasi pembelajaran yang dapat digunakan sebagai bahan evaluasi di dalam kelas.

\section{Tahap Prototyping (Validasi, Evalusi, Revisi)}

Tahap perancangan dimulai dengan pengembangan kisi-kisi soal berdasarkan materi yang telah dipilih yaitu struktur sosial, diferensiasi sosial dan stratifikasi sosial. Dari kisi-kisi yang telah dikembangkan tersebut peneliti menentukan bentuk soal yang akan dikembangkan. Rancangan soal open ended ini menghasilkan kisi-kisi soal untuk soal pilihan ganda dengan banyak pilihan jawaban dan uraian/essay disertai alasan. Adapun langkah pada tahap perancangan soal ini adalah sebagai berikut: (1) perancangan indikator, (2) meranng pedoman cara pengisian, (3) merancang pertanyaan terbuka open-ended sesuai kisi-kisi yang sudah dirancang, (4) membuat lembar jawaban, (5) merancang kunci jawaban, (6) dan yang terakhir adalah membuat pedoman penskoran. Berikut adalah kisi-kisi soal open ended untuk materi struktur sosial, diferensiasi sosial dan stratifikasi sosial.

\section{Penilaian Pakar}

Pada tahap pengembangan, peneliti melakukan uji validasi produk yang telah dirancang pada tahap perancangan kepada 3 orang ahli/pakar. Validasi soal open ended ini dilakukan oleh 3 orang validator yaitu dua orang dosen dari Jurusan Sosiologi FIS UNP; dan satu orang guru sosiologi di SMA N 1 Sungai Aur. Hasil validasi rancangan soal open ended yang peneliti kembangkan dapat dilihat pada tabel di bawah ini:

Tabel 3. Penilaian Uji Validasi Validator

\begin{tabular}{|c|c|c|c|c|}
\hline No & Aspek dan Uraian & Ahli 1 & Ahli 2 & Ahli 3 \\
\hline A. & Materi & & & \\
\hline 1. & Soal sesuai dengan indikator pembelajaran & 4 & 4 & 5 \\
\hline 2. & $\begin{array}{l}\text { Soal sesuai dengan materi perbedaan, } \\
\text { kesetaraan dan harmoni sosial di } \\
\text { SMA/MA/Sederajat }\end{array}$ & 5 & 4 & 5 \\
\hline 3. & Soal mempunyai satu jawaban benar & 4 & 3 & 5 \\
\hline 4. & Pengecoh berfungsi & 4 & 4 & 4 \\
\hline 5. & $\begin{array}{l}\text { Waktu yang disediakan cukup untuk } \\
\text { menyelesaikan soal }\end{array}$ & 5 & 4 & 4 \\
\hline \multicolumn{5}{|c|}{ Persentase Skor Penilaian Ahli $=85,4 \%$} \\
\hline B. & Konstruksi & & & \\
\hline 1. & Soal terbaca jelas & 4 & 4 & 5 \\
\hline 2. & $\begin{array}{l}\text { Jenis huruf, ukuran dan spasi yang digunakan } \\
\text { pas/sesuai }\end{array}$ & 4 & 3 & 5 \\
\hline
\end{tabular}

Jurnal Sikola: Jurnal Kajian Pendidikan dan Pembelajaran Vol. 2, No. 3, Th. 2021 


\begin{tabular}{|c|c|c|c|c|}
\hline 3. & $\begin{array}{l}\text { Pokok soal tidak mengandung pernyataan } \\
\text { negatif ganda }\end{array}$ & 4 & 4 & 4 \\
\hline 4. & Pokok soal dirumuskan dengan jelas & 4 & 4 & 4 \\
\hline 5. & $\begin{array}{l}\text { Pokok soal tidak memberi petunjuk ke arah } \\
\text { jawaban yang benar }\end{array}$ & 4 & 4 & 4 \\
\hline 6. & $\begin{array}{l}\text { Kalimat yang digunakan tidak menimbulkan } \\
\text { penafsiran ganda }\end{array}$ & 4 & 3 & 5 \\
\hline 7. & Panjang rumusan jawaban relatif sama & 4 & 4 & 5 \\
\hline 8. & $\begin{array}{l}\text { Pilihan jawaban yang disajikan homogen dan } \\
\text { logis }\end{array}$ & 4 & 4 & 5 \\
\hline 9. & $\begin{array}{l}\text { Pilihan jawaban tidak mengandung } \\
\text { pernyataan "semua jawaban benar" atau } \\
\text { "semua jawaban salah" }\end{array}$ & 5 & 4 & 5 \\
\hline 10. & Gambar atau tabel jelas dan berfungsi & 5 & 5 & 5 \\
\hline 11. & $\begin{array}{l}\text { Butir soal tidak bergantung pada jawaban soal } \\
\text { sebelumnya }\end{array}$ & 5 & 5 & 5 \\
\hline \multicolumn{5}{|c|}{ Persentase Skor Penilaian Ahli = 86,7\% } \\
\hline C. & Bahasa & & & \\
\hline 1. & Bahasa yang digunakan komunikatif & 4 & 3 & 5 \\
\hline 2. & $\begin{array}{l}\text { Bahasa yang digunakan sesuai dengan kaidah } \\
\text { bahasa indonesia }\end{array}$ & 3 & 4 & 5 \\
\hline 3. & $\begin{array}{l}\text { Tidak menggunakan bahasa yang berlaku di } \\
\text { daerah setempat }\end{array}$ & 5 & 4 & 4 \\
\hline 4. & $\begin{array}{l}\text { Bahasa yang digunakan mudah dipahami oleh } \\
\text { peserta didik }\end{array}$ & 5 & 4 & 5 \\
\hline
\end{tabular}

Sumber: Data Primer 2020

Berdasarkan data hasil validasi soal open ended oleh validator ahli materi, pada variabel materi memiliki 5 indikator mendapatkan nilai validitas $85,44 \%$, sedangkan untuk variabel konstruksi soal diperoleh nilai validitas $86,7 \%$, yang terakhir dari variabel bahasa mendapatkan nilai validitas $85 \%$. Sehingga didapatkan skor akhir $85,71 \%$ (sangat baik). Berdasarkan hasil analisis dan validasi ahli terhadap produk yang dikembangkan, secara holistik dari aspek materi, soal kepraktisan produk sudah baik, namun ada beberapa aspek yang perlu direvisi kembali agar produk rancangan soal open ended benar-benar layak untuk digunakan.

Berikut ini adalah saran dan masukan validator terkait rancangan soal open ended pada materi struktur sosial, diferensiasi sosial dan stratifikasi sosial yang diasumsikan dapat mengingkatkan kemampuan penalaran peserta didik.

\section{Tabel 4. Saran dan Masukan Validator Revisi Produk}

\begin{tabular}{lccccc} 
No & Validator & Instrumen & \multicolumn{2}{c}{ Saran revisi } & Keterangan \\
\hline 1 & Validator 1 & Soal & 1. Perbanyak jumlah soalnya dan & Sudah \\
& & jangan hanya terpaku pada & direvisi \\
& & Soal yang telah ada & dengan \\
& & 2. Konstruksi materi lebih & membuat \\
\hline
\end{tabular}

Jurnal Sikola: Jurnal Kajian Pendidikan dan Pembelajaran Vol. 2, No. 3, Th. 2021 
Panji Reski, Ike Sylvia Rancangan Soal Open-Ended Untuk Meningkatkan Kemampuan Penalaran Peserta Didik Dalam Pembelajaran Sosiologi di SMA N 1 Sungai Aur Kabupaten Pasaman Barat

\begin{tabular}{|c|c|c|c|}
\hline & & $\begin{array}{l}\text { diperluas lagi } \\
\text { 3. Perbaiki ketikan dan pahami } \\
\text { lagi urutuan kompetensi dan } \\
\text { sub-sub konsep yang tepat }\end{array}$ & $\begin{array}{l}\text { varias soal } \\
\text { yang sesuai } \\
\text { materi }\end{array}$ \\
\hline 2 & Validator 2 & $\begin{array}{l}\text { 1. Perbanyak lagi soalnya dan } \\
\text { disesuaikan materi dengan } \\
\text { indikatornya } \\
\text { 2. Tambah juga soal uraian/essay } \\
\text { agar peserta didik bisa } \\
\text { meningkatkan kemampuan } \\
\text { penalaran } \\
\text { 3. Ada beberapa bahasa yang } \\
\text { perlu diperbaiki } \\
\text { 4. Pahami lagi konsep soal open- } \\
\text { ended dan tambahkanlah soal } \\
\text { uraian untuk mengasah } \\
\text { kemampuan penalaran peserta } \\
\text { didik }\end{array}$ & $\begin{array}{c}\text { Sudah } \\
\text { direvisi } \\
\text { dengan } \\
\text { menambah } \\
\text { kan } 5 \text { soal } \\
\text { essay open } \\
\text { ended }\end{array}$ \\
\hline 3 & Validator 3 & $\begin{array}{l}\text { 1. Rapikan lagi penulisan, } \\
\text { paragraf dan tata letak soal } \\
\text { "Tab" } \\
\text { 2. Masih banyak yang typo coba } \\
\text { perbaiki lagi }\end{array}$ & $\begin{array}{l}\text { Sudah } \\
\text { direvisi }\end{array}$ \\
\hline
\end{tabular}

Berdasarkan saran validator di atas peneliti kemudian memperbaiki kisi-kisi soal dan soal. Perbaikan kisi-kisi tersebut dapat dilihat pada tabel di bawah ini:

Tabel 5. Kisi-kisi Soal Open Ended (Pilihan Ganda)

\begin{tabular}{|c|c|c|c|c|c|c|}
\hline \multirow[t]{2}{*}{ No } & \multirow[t]{2}{*}{ Indikator } & \multicolumn{4}{|c|}{ Aspek Kognitif } & \multirow{2}{*}{$\begin{array}{c}\text { Jumlah } \\
\text { Soal }\end{array}$} \\
\hline & & C3 & C4 & C5 & C6 & \\
\hline 1 & $\begin{array}{l}\text { Disajikan Ilustrasi, peserta didik mampu } \\
\text { menunjukkan realitas struktur sosial di } \\
\text { masyarakat }\end{array}$ & & 1 & & & 1 \\
\hline 2 & $\begin{array}{l}\text { Disajikan Kasus, peserta didik mampu } \\
\text { menunjukkan bentuk-bentuk struktur } \\
\text { sosial yang ada di masyarakat }\end{array}$ & & 1 & & & 2 \\
\hline 3. & $\begin{array}{l}\text { Disajikan Gambar, peserta didik mampu } \\
\text { menunjukkan hubungan dari struktur } \\
\text { sosial }\end{array}$ & & 1 & & & 3 \\
\hline 4. & $\begin{array}{l}\text { Disajikan Fakta, peserta didik mampu } \\
\text { menyimpulkan status dan peran di } \\
\text { masyarakat }\end{array}$ & & 1 & & & 4 \\
\hline 5 . & $\begin{array}{l}\text { Disajikan Pernyataan, peserta didik } \\
\text { mampu menunjukkan realitas dari jenis- } \\
\text { jenis status sosial }\end{array}$ & & 1 & & & 5 \\
\hline 6. & $\begin{array}{l}\text { Disajikan Ilustrasi, peserta didik mampu } \\
\text { menganalisis cara melakukan perubahan } \\
\text { status sosial di masyarakat }\end{array}$ & & & 1 & & 6 \\
\hline 7. & Disajikan Pernyataan, peserta didik & & 1 & & & 7 \\
\hline
\end{tabular}

Jurnal Sikola: Jurnal Kajian Pendidikan dan Pembelajaran Vol. 2, No. 3, Th. 2021 
mampu menganalisis realitas struktur

sosial di masyarakat

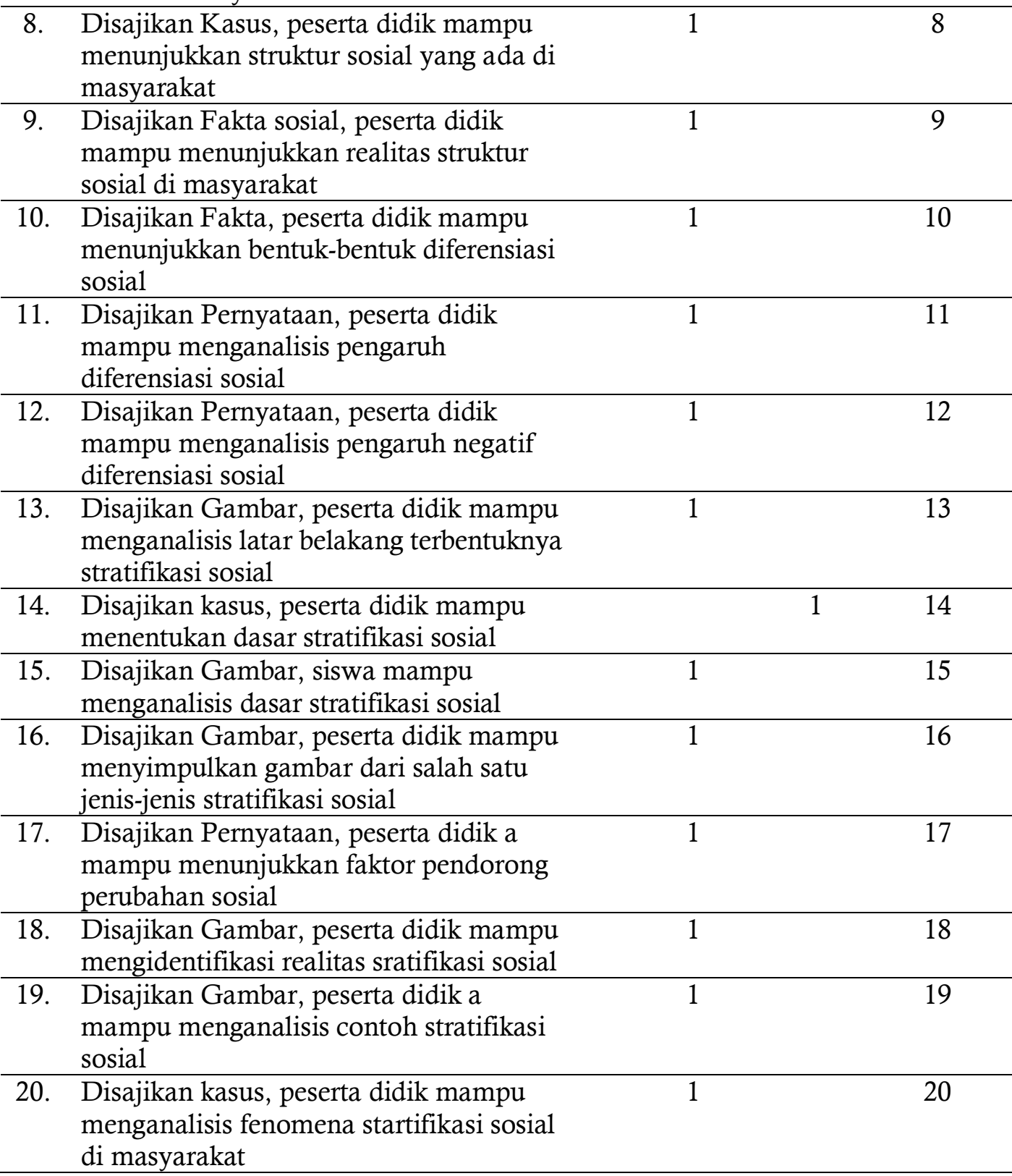

Selanjutnya peneliti juga mengembangkan soal uraian/essay dengan bentuk open ended seperti terdapat pada kisi-kisi di bawah ini:

Tabel 6. Kisi-Kisi Soal Open Ended (Uraian/Essay)

\begin{tabular}{|c|c|c|c|c|c|c|}
\hline \multirow[t]{2}{*}{ No } & \multirow[t]{2}{*}{ Indikator } & \multicolumn{4}{|c|}{ Aspek Kognitif } & \multirow{2}{*}{$\begin{array}{c}\text { Jumlah } \\
\text { Soal }\end{array}$} \\
\hline & & C3 & C4 & $\mathbf{C 5}$ & C6 & \\
\hline 1. & $\begin{array}{l}\text { Disajikan Pertanyaan, peserta didik } \\
\text { mampu menganalisis jenis-jenis status } \\
\text { sosial di masyarakat }\end{array}$ & & 1 & & & 1 \\
\hline 2. & Disajikan Pertanyaan, peserta didik & & 1 & & & 2 \\
\hline
\end{tabular}

Jurnal Sikola: Jurnal Kajian Pendidikan dan Pembelajaran Vol. 2, No. 3, Th. 2021 
mampu mengidentifikasi bentuk

stratifikasi sosial yang ada

dimasyarakat

3. Disajikan Pertanyaan, peserta didik

mampu mengidentifikasi bentuk

diferensiasi sosial yang ada

dimasyarakat

4. Disajikan kasus, peserta didik a mampu

mengidentifikasi kasus yang dan mengaitkannya dengan pelapisan sosial

di masyarakat

5. Disajikan gambar, peserta didik mampu

menganalisis gambar dan

menghubungkannya dengan emansipasi

wanita pada masa sekarang

\section{Uji coba One to One}

Soal open-ended untuk pembelajaran sosiologi materi kelas XI materi struktur sosial, diferensiasi sosial dan stratifikasi sosial diuji cobakan one to one pada seorang murid kelas XI IPS 2 SMA N 1 Sungai Aur yaitu NZ untuk mengetahui keterbacaan dan kesulitan serta saran-saran terhadap soal tersebut. Berikut kemampuanpeserta didik menjawab salah satu soal yang diujikan.

13. Perhatikan gambar piramida berikut!

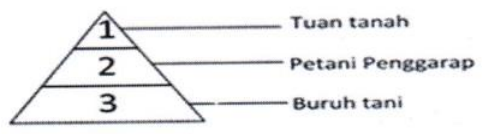

Latar belakang terbentuknya stratifikasi sosial pada piramida tersebut adalah...

1. Sistem pembagian tugas

2. Sistem pembagian tanah

3. Kemajuan sistem ekonomi

4. Sistem kepemilikan tanah

5. Perbedaan pekerjaan petani

Pilihan :

A. Jika (1), (2), dan (3) yang benar

B. Jika (1) dan (3) yang benar

C. Jika Jawaban (2) dan (4) yang benar

D. Jika Jawaban (4) benar

E. Jika semua jawaban (1), (2), (3) dan (4) benar

Alasan Memilih Jawaban :

karena kaizu melihat. duri. pir amida . fang a ada pad z...

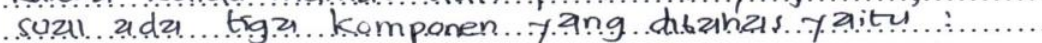

ä) Tuan Tanạh sba pemilik tanzat

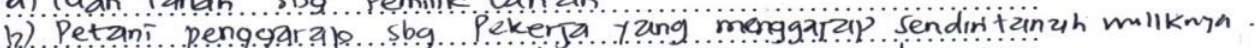

c) Buruh Tani petani 79 tidak punya tanah dan de bekerg

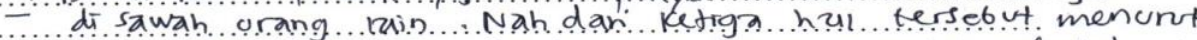

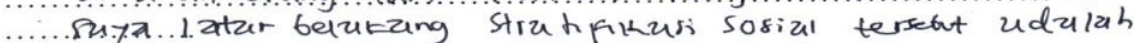
berdasarkan sistem legemilitzen tunahnya

Gambar 2. Contoh Jawaban Peserta Didik Pada Uji One to One 


\section{Uji Coba Small Group}

Penelitian rancangan soal open ended untuk meningkatkan kemampuan penalaran peserta didik dalam pembelajaran sosiologi di SMA N 1 Sungai Aur ini tidak diimplementasikan pada uji lapangan atau field test namun hanya pada small group yaitu 10 orang peserta didik di kelas XI IPS 2 yang bukan subjek penelitian. Soal open-ended pada prototipe ke dua merupakan revisi dari tahapan validasi pakar dan one to one. Diakhir uji coba small group, peserta didik diminta memberikan komentar secara umum, mengenai soal tes yang telah dikerjakannya. Peneliti melakukan analisis butir soal untuk menguji validitas soal berdasarkan jawaban dari 10 orang peserta didik di keals XI IPS 2 SMA N 1 Sungai Aur. Berdasarkan analisis butir soal disimpulkan bahwa ada 20 soal pilihan ganda dan 5 soal essay yang valid dan siap untuk diujicoba lapangan pada saat penilaian harian guru pada materi struktur sosial, diferensiasi sosial dan stratifikasi sosial.

\section{Analisis Keberagaman Solusi Jawaban Soal Open Ended Peserta Didik}

Peneliti melakukan analisis terhadap variasi solusi yang diberikan oleh peserta didik dalam menjawab soal yang diberikan. Berikut secara terperinci rekap variasi jawaban soal open ended peserta didik pada uji small group.

Tabel 7. Analisis Keberagaman Alasan Jawaban Soal Open Ended Peserta Didik

\begin{tabular}{cccccc} 
& \multicolumn{5}{c}{ Keberagaman Alasan Solusi Jawaban } \\
No Soal & \multicolumn{5}{c}{ Soal Open Ended Peserta Didik } \\
\cline { 2 - 6 } & $\mathbf{1}$ & $\mathbf{2}$ & $\mathbf{3}$ & $\mathbf{4}$ & $\mathbf{5}$ \\
\hline $\mathbf{1}$ & 1 & 2 & 4 & 3 & 0 \\
$\mathbf{2}$ & 2 & 2 & 3 & 2 & 1 \\
$\mathbf{3}$ & 2 & 2 & 4 & 1 & 1 \\
$\mathbf{4}$ & 1 & 3 & 3 & 2 & 1 \\
$\mathbf{5}$ & 1 & 2 & 4 & 3 & 0 \\
$\mathbf{6}$ & 1 & 4 & 5 & 0 & 0 \\
$\mathbf{7}$ & 1 & 2 & 6 & 1 & 0 \\
$\mathbf{8}$ & 0 & 2 & 5 & 3 & 0 \\
$\mathbf{9}$ & 0 & 4 & 4 & 1 & 1 \\
$\mathbf{1 0}$ & 0 & 4 & 3 & 1 & 2 \\
$\mathbf{1 1}$ & 0 & 3 & 3 & 3 & 1 \\
$\mathbf{1 2}$ & 1 & 3 & 3 & 1 & 2 \\
$\mathbf{1 3}$ & 1 & 3 & 3 & 3 & 0 \\
$\mathbf{1 4}$ & 2 & 4 & 4 & 0 & 0 \\
$\mathbf{1 5}$ & 0 & 4 & 4 & 2 & 0 \\
$\mathbf{1 6}$ & 0 & 4 & 4 & 1 & 1 \\
$\mathbf{1 7}$ & 0 & 3 & 4 & 2 & 1 \\
$\mathbf{1 8}$ & 1 & 4 & 4 & 1 & 0 \\
$\mathbf{1 9}$ & 1 & 3 & 3 & 3 & 0 \\
$\mathbf{2 0}$ & 1 & 4 & 3 & 2 & 0 \\
\hline Jumlah & 16 & 62 & 76 & 35 & 11 \\
\hline & & & & &
\end{tabular}

Data di atas memperlihatkan bahwa dari 10 orang peserta didik yang mengikuti small group tes soal open ended untuk materi struktur sosial, diferensiasi sosial dan stratifikasi sosial, paling banyak mampu mengungkapkan 3 alasan jawaban terhadap soal yang ditanyakan, kemudian diiukuti dengan mampu mengemukakan 2 alasan/solusi, selanjutnya 4 alasan atau solusi, dan sedikit mampu mengungkapkan 5 alasan pendukung jawaban yang dipilihnya. Hal 
ini memperlihatkan sebenarnya peserta didik mampu dilatih untuk mengemukakan pendapatnya terkait dengan alternatif alasan atau solusi terhadap soal yang dibacanya dan dapat dilatih untuk mengingkatkan kemampuan penalaran peserta didik.

Mahmudi (Mahmudi, 2008) menyatakan bahwa aspek keterbukaan dalam soal terbuka (open ended) dapat diklasifikasikan ke dalam tiga tipe yaitu : (1) terbuka proses penyelesaiannya, yakni soal memiliki beragam cara penyelesaian, (2) terbuka hasil akhirnya, yakni soal tersebut memiliki banyak jawaban yang benar, (3) pengembangan lanjutan, yakni ketika peserta didik telah menyelesaikan sesuatu, selanjutnya mereka dapat mengembangkan soal baru dengan mengubah syarat atau kondisi soal yang telah diselesaikan. Pada penelitian ini peneliti mengembangkan soal open ended dengan tip kedua yaitu rancangan soal yang dikembangkan terbuka hasil akhirnya artinya penelitia mengemukakan beberapa jawaban benar dan peserta didik dapat menuliskan alternatif jawaban yang sesuai disertai dengan alasan mereka.

Rancangan soal open ended ini memiliki keunggulan dan kekurangan tersendiri. Sesuai yang dikemukakan Shimada (Soeyono, 2013): a) Kelebihan 1) Peserta didik berpartisipasi aktif dalam pembelajaran dan sering mengekspresikan idenya sendiri, 2) Peserta didik memiliki kesempatan lebih banyak dalam memanfaatkan pengetahuan dan ketrampilan secara komprehensif, 3) Peserta didik dengan kemampuan rendah dapat merespon permasalahan dengan cara mereka sendiri, 4) Peserta didik secara intrinsik termotivasi untuk memberikan penjelasan, 5) Peserta didik memiliki banyak pengalaman dalam menemukan jawaban dari permasalahan. Penjelasakan di atas dapat menjadi landasan analisis hasil penelitian yang peneliti peroleh bahwa peserta didik yang awalnya terbiasa menjawab soal rutin dan berada pada tingkat berpikir LOTS dan MOTS $(\mathrm{C} 1-\mathrm{C} 3)$ ternyata dapat menjawab soal dengan tingkat berpikir HOTS (C4 - C6). Selain itu peserta didik juga mampu mengembangkan idenya, memanfaatkan pengetahuan dan keterampilannya, termotivasi memberikan jawaban dan menemukan banyak pengalaman untuk menghadapi sebuah permasalahan, akhirnya proses pengerjaan soal open ended dapat membantu peserta didik mengaktifkan kemampuan penalarannya. Terdapat 4 fase tahapan Open-Ended Approach yang dapat mengaktifkan kemampuan peserta didik yaitu: (1) Fase 1, Open-ended Problems yaitu peserta didik dihadapkan pada masalah terbuka yang memiliki lebih dari satu jawaban atau metode penyelesaian, (2) Fase 2, Contructivism yaitu peserta didik menemukan pola untuk mengonstruksi permasalahan sendiri, (3) Fase 3, Eksploration yaitu peserta didik menyelesaikan masalah dengan banyak cara penyelesaian untuk kegiatan eksplorasi, (4) Fase 4, Presentation yaitu peserta didik menyajikan hasil temuannya. (Eka, Lestari Karunia \& Yudhanegara, 2015).

Berdasarkan pemaparan kelebihan-kelebihan dari pendekatan open-ended dapat disimpulkan bahwa salah satu keunggulan soal open-ended adalah dapat meningkatkan kemampuan penalaran pada peserta didik. Ciri dari pendekatan open-ended adalah pendekatan pembelajaran yang dimulai dengan pemberian masalah terbuka kepada peserta didik. Masalah terbuka adalah masalah yang diformulasikan bisa dalam bentuk soal dengan multi jawaban atau permasalahan yang memiliki banyak jawaban benar atau banyak cara penyelesaian yang tepat. Pada penelitian ini, menerapkan pendekatan open-ended untuk menyelesaikkan soal dengan tingkat kemampuan C3 - C6 pada materi struktur sosial, diferensiasi sosial dan stratifikasi sosial. Beragam alternatif jawaban disediakan agar peserta didik dapat memilih jawaban yang paling tepat dengan kengemukakan beberapa alternatif jawaban. Sesuai dengan penjabaran di atas maka tahapan dalam pembelajaran yang dapat membantu peserta didik mengaktifkan kemampuan penalaran peserta didik.

Tahapan yang dilaksanakan dalam proses menjawab soal open ended sesuai dengan apa yang diharapkan oleh teori konstruktivis didefinisikan sebagai pembelajaran yang bersifat generatif, yaitu tindakan mencipta sesuatu makna dari apa yang dipelajari atau membina pengetahuan berasaskan pengalaman yang sudah ada. Pembelajaran konstruktivis mengutamakan keaktifan peserta didik dalam mengkonstruksikan pengetahuan berdasarkan

Jurnal Sikola: Jurnal Kajian Pendidikan dan Pembelajaran Vol. 2, No. 3, Th. 2021 
pengalamannya dalam belajar. Peserta didik mempunyai akses terhadap berbagai sumber informasi yang dapat digunakan untuk belajar. Perilaku dari pembelajaran konstruktivis menunjukkan kemampuan peserta didik untuk menghasilkan sesuatu (generate), menunjukkan suatu kinerja (demonstrate performance), dan memamerkan hasil karyanya kepada umum (exhibit), sehingga bukan hanya mengulang apa yang diajarkan guru (Brooks, J.G \& Brooks, 1993). Menurut paham konstruktivis, dalam proses belajar mengajar guru tidak serta merta memindahkan pengetahuan kepada peserta didik dalam bentuk yang serba sempurna. Dengan kata lain, pesera didik harus membangun suatu pengetahuan itu berdasarkan pengalamannya masing-masing. Pembelajaran adalah hasil dari usaha peserta didik itu sendiri dan guru tidak boleh belajar untuk peserta didik. Pikiran peserta didik tidak akan menghadapi kenyataan dalam bentuk yang terasing dalam lingkungan sekitar. Realita yang diketahui peserta didik adalah realita yang dia bina sendiri, peserta didik sebenarnya telah mempunyai satu set ide dan pengalaman yang membentuk struktur kognitif terhadap lingkungan.

\section{Kesimpulan}

Penelitian ini telah menghasilkan suatu produk soal open-ended untuk melatih kemampuan penalaran pada materi materi struktur sosial, diferensiasi sosial dan stratifikasi sosial yang valid. Valid tergambar dari hasil penilaian validator, dimana semua validator menyatakan sudah baik berdasarkan: (1) Content yaitu sesuai kompetensi dasar dan tujuan pembelajaran, (2) konstruk (sesuai dengan teori dan kriteria soal open-ended yang dapat melatih kemampuan penalaran), dan (3) bahasa (sesuai dengan kaidah bahasa yang berlaku). Kevalidan soal open-ended ini tergambar setelah dilakukan analisis validasi butir 20 pilihan ganda disertai alasan dan 5 soal uraian/essay yang diujikan pada small group peserta didik yang berjumlah 10 orang di kelas XI IPS 2 SMA N 1 Sungai Aur Kabupaten Pasaman Barat. Kepraktisan soal tergambar dari hasil uji coba small group dimana sebagian besar siswa dapat menyelesaikan soal open-ended yang diberikan dan mampu mengungkapkan alasan.

\section{Daftar Pustaka}

Adi, N. (2010). Pelaksanaan Evaluasi Hasil Belajar Mahasiswa. Jurnal Pendidikan Dan Kebudayaan, 16(9), 321-327. https://doi.org/https://doi.org/10.24832/jpnk.v16i9.523

Brooks, J.G \& Brooks, M. . (1993). In Search of Understanding: The Case for Constructivist Classrooms. Alexandria: VA: Association for Supervision and Curriculum Development.

Dahlan, J. A., Rohayati, A., \& Karso, K. (2012). Implementasi Strategi Pembelajaran Konflik Kognitif Dalam Upaya meningkatkan High Order Mathematical Thingking Siswa. Jurnal Pendidikan, 13(2), 65-76. https://doi.org/10.33830/jp.v13i2.372.2012

Dessy Febyronita, G. (2016). Survei Tingkat Kemampuan Siswa Dalam Mengerjakan Tes Berbentuk Jawaban Singkat (Short Answer Test) Pada Mata Pelajaran IPS Terpadu (Geografi) Kelas VII di SMP Negeri 1 Mesuji Tahun Pelajaran 2015/2016. Jurnal Swarnabhum, 1(1), 17-23.

Eka, Lestari Karunia \& Yudhanegara, M. (2015). Penelitian Pendidikan Matematika. Bandung: Refika Aditama.

Kemendikbud. Permendikbud No. 21 Tahun 2016 tentang Standar Isi Pendidikan Dasar dan Menengah., (2016).

Konita, M., Asikin, M., \& Noor Asih, T. S. (2019). Kemampuan Penalaran Matematis dalam Model Pembelajaran Connecting, Organizing, Reflecting, Extending. Proseding Seminar Nasional Matematika, 2, 611-615.

Mahmudi, A. (2008). Pembelajaran Problem Posing untuk Meningkatkan Kemampuan Pemecahan Masalah Matematika. Yogyakarta: Seminar Nasional Matematika. 
Mardiani, M., \& Sylvia, I. (2019). Pengembangan Tes Diagnostik Pilihan Objektif Tiga Tingkat Guna Mendeteksi Miskonsepsi Ciri-Ciri Sosiologi. Jurnal Sikola: Jurnal Kajian Pendidikan Dan Pembelajaran, 1(1), 69-79. https://doi.org/10.24036/sikola.v1i1.1

Melianingsih, M., Nuning, N., \& Sugiman, S. (2015). Keefektifan Pendekatan Open-Ended Dan Problem Solving Pada Pembelajaran Bangun Ruang Sisi Datar di SMP. Riset Pendidikan Matematika, 2(1), 211-223. https://doi.org/https://doi.org/10.21831/jrpm.v2i2.7335

Retnawati, H. (2016). Analisis Kuantitatif Instrumen Penelitian. Yogyakarta: Parama Publishing.

Soeyono, Y. (2013). Mengasah Kemampuan Berpikir Kritis Dan Kreatif Siswa Melalui Bahan Ajar Matematika Dengan Pendekatan Open-Ended. Yogayakarta: Prosiding Nasional Matematika dan Pendidikan Matematika.

Sugiyono, S. (2017). Metode Penelitian Kuantitatif, Kualitatif, dan R\&D. Jakarta: Alfabeta.

Sylvia, I., Anwar, S., \& Khairani, K. (2019). Pengembangan Instrumen Penilaian Autentik Berbasis Pendekatan Authentic Inquiry Learning Pada Mata Pelajaran Sosiologi di Sekolah Menengah Atas. Socius, 6(2), 103-120. https://doi.org/10.24036/scs.v6i2.162

Yusuf, A. M. (2015). Asesmen dan Evaluasi Pendidikan. Jakarta: Prenada Media Grup.

Z Lewy, N. A. (2009). The Development of Test to Measure High Level Thinking. Journal of Mathematics Education, 3(2), 14-28. 